Journal of Educational Technology

\& Online Learning

Volume 2 | Issue 3 | 2019

http://dergipark.gov.tr/jetol

\title{
Augmented Reality: Historical Development and Area of Usage
}

\section{İbrahim SÜNGER ${ }^{\mathrm{a}}$}

Serkan ÇANKAYA ${ }^{\mathrm{b}}$

a egitimteknologunuz@gmail.com; ORCID: 0000-0002-3319-7124

b serkan.cankaya@idu.edu.tr, İzmir Democracy Unviersity, İzmir, Turkey; ORCID: 0000-0002-3951-9809

Doi: $10.31681 /$ jetol.615499

Suggested citation: Sünger, İ. \& Çankaya, S. (2019). Augmented reality: historical development and area of usage. Journal of Educational Technology and Online Learning, 2(3), 118-133.

\section{Article Info}

Received: 04.09 .2019

Revised : 24.09.2019

Accepted: 30.09 .2019

Review Article

\section{Abstract}

Technological developments bring along lots of innovations. One of the innovations that have become widespread in recent years is the concept of augmented reality. In current scientific literature there are a lot of studies in literature about augmented reality which can be defined as the combination of real and virtual worlds, experienced by humans in a unified view. Aim of this study is to present the historical development and area of usage of augmented reality. This study will hopefully provide a timely insight into the current state of research on the use of augmented reality.

Keywords: augmented reality, literature review, mixed reality, virtual reality

\section{INTRODUCTION}

Virtual Reality (VR) is a completely interactive virtual environment created by computers with visuals and complex data. In virtual reality, users have no connection with the physical world (Aukstakalnis and Blatner as cited in Isdale, 1993). On the other hand, augmented reality is a variation of virtual reality which enriches real world with virtual elements (Azuma, 1997). To make it more understandable, Milgram and Kishino (1994) presents the terms in the following diagram (Figure 1).

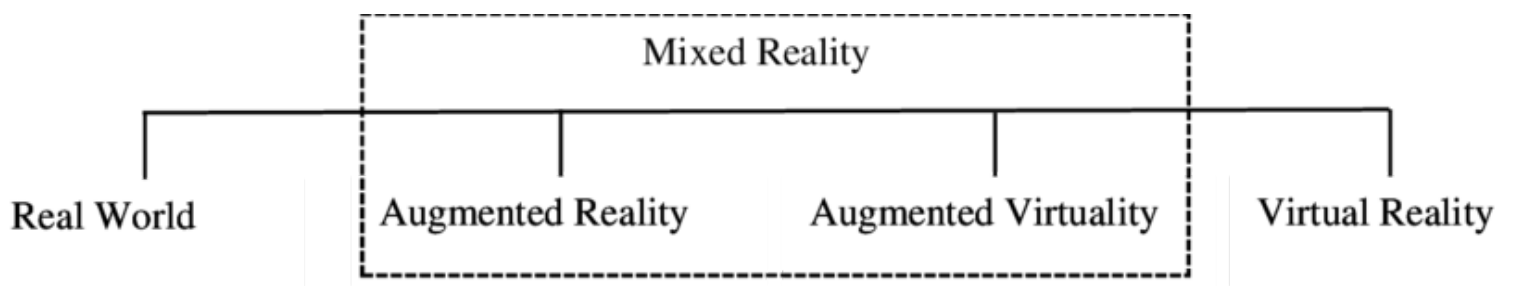

Figure 1. Virtuality Continuum (Milgram \& Kishino, 1994)

There are two terms, augmented reality and augmented virtuality between real world and virtual reality. According to the Figure 1 it can be said that augmented reality is closer to the real word than augmented virtuality. 
Development of augmented reality started in 1950s. First of all, Morton L. Heilig invented Sensorama which was considered the earliest example of augmented reality. And then the term augmented reality was first used by Thomas Caudell and David Mizell in 1992 (Caudell \& Mizell, 1992). After that time with the developments in technology and mobile technology, the use of augmented reality increased enormously. Besides number of academic studies about augmented reality has increased with the growth of academic interest. A search in the database of Scopus, which is an important database in academic world (Scopus, 2019), with "augmented reality" keyword revealed the results presented in Figure 2 regarding the number of related studies by year. A total of 23474 studies were reached.

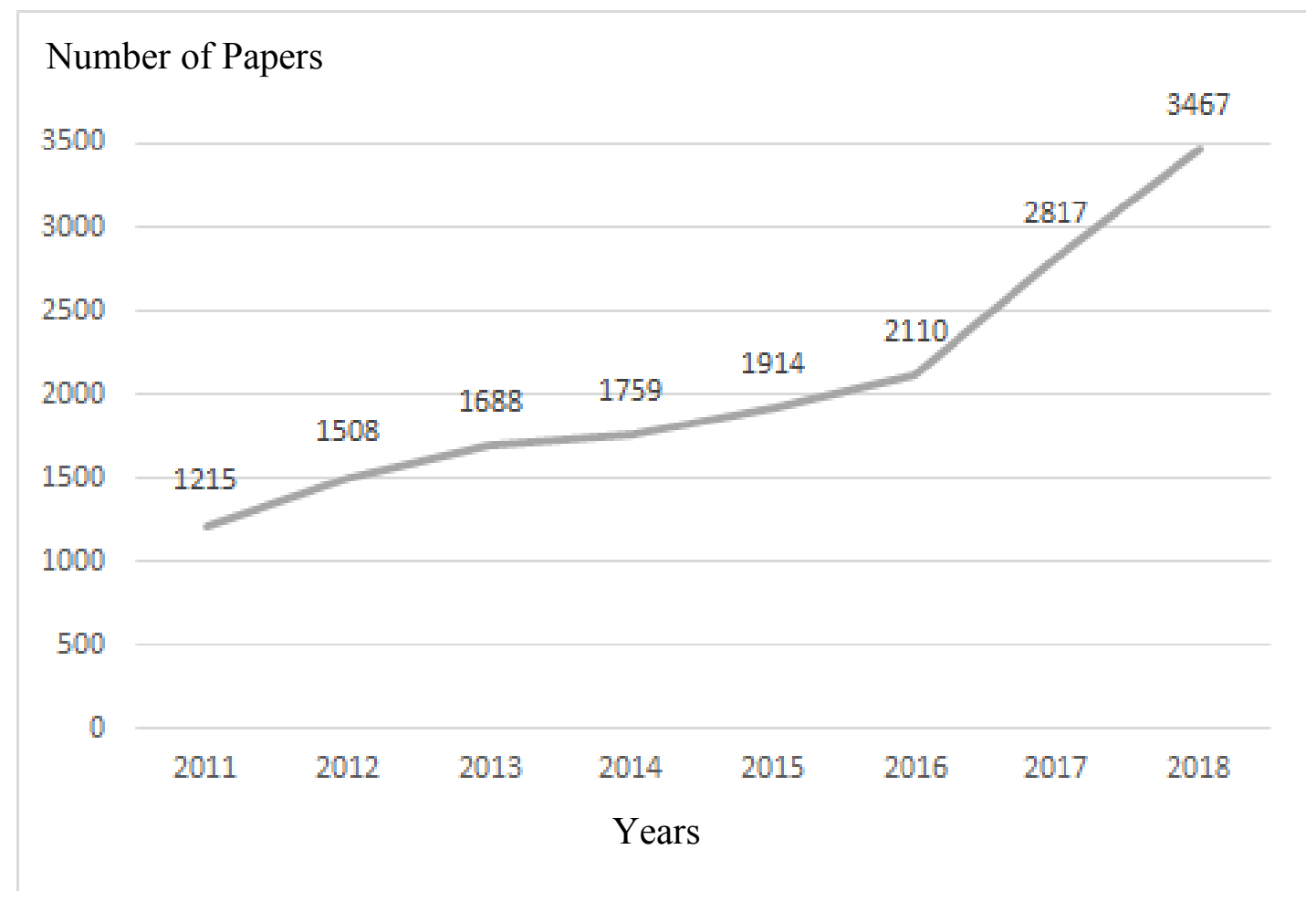

Figure 2. Number of Papers in Scopus Database

As can be seen in Figure 2, there has been a gradual increase in the number of studies conducted on augmented reality. Especially in recent years, this term became widespread, and its use increased gradually. It is important to track, summarize and evaluate new applications in technology. By mapping the developments about augmented reality, this review will hopefully provide a timely insight into the current state of research on augmented reality. In this respect, the aim of this paper is to present the historical development and area of usage of augmented reality. 


\section{LITERATURE}

In this part, historical development, hardware and software components of augmented reality and its area of usage will be explained.

\section{Definitions of Augmented Reality}

Augmented reality requires technology that provides interactive virtual components and physical components simultaneously (Azuma, 1997). According to another definition, augmented reality means the enrichment of real-world places and objects with virtual places and objects created in computerized environments (Altınpulluk, 2015). Augment reality technology can make some experiences possible that otherwise seem to be very hard or impossible to implement. In addition, augmented reality has the potential that the senses like touching, smelling, and tasting can be targeted in augmented reality environments (Craig as cited in Altınpulluk, 2015).

Augmented reality applications can be performed with different kind of devices like cell phones, tablets, head mounted displays. Based on this application variety, Ludwig and Reimann (2005) defined augmented reality as "human computer interaction that adds virtual objects to real senses that are provided by a video camera in real time". According to the definition of Kapp and Balkun (2011), "augmented reality is a predominantly real-world space in which virtual elements are inserted in real time." According to the Ronald Azuma, who is one of the pioneer researchers in the field, augmented reality has three distinctive features:

- Combination of real and virtual

- Real time interaction

- $\quad$ 3D objects (Azuma, 1997).

\section{Historical Development of Augmented Reality}

The first idea about augmented reality was introduced unintentionally by L. Frank Baum in 1901. In the novel of The Master Key, he describes special eyeglasses. The person who wears them, sees everyone with a letter marked upon his or her forehead indicating his or her character. The good bears the letter ' $G$,' the evil the letter ' $E$ ', the foolish the letter ' $F$ ', etc. Thus, it is possible to determine the true natures of people by a single look. This usage is accepted to be the first idea of augmented reality (Woods, 2014).

Sensorama was the machine developed by Morton Heilig in 1957 which was the earliest example of multisensory immersive technology copyrighted in 1962. The Sensorama device included a stereoscopic color display, fans, odor emitters, stereo-sound system, and a motional chair. These features targeted different senses of the users. It can be said that it looked like a 
game machine in game arcade rooms. And it was a very important development in term of augmented reality literature in that time (Sung, 2011).

After the development of sensorama machine, another important development was performed by Ivan Sutherland who was a professor of electric engineering in Harvard Unviersity and his student Bob Sproull in 1966. They developed first head mounted display which its technologically developed versions are still in use nowadays in the virtual reality and augmented reality environments. This device was called Sword of Democles (Sutherland, 1968). Of course, its processor and graphics capabilities were limited due to the technological developments of that time (Sung, 2011). Although it had limitations, it can be said that these devices are considered as the birth of modern augmented reality applications.

The first use of the term augmented reality was made by two researchers of the Boing Company. They designed a head mounted display to ease the cable assembling process, which is a very complex process and is prone to errors, in plane production phase, by pointing the correct cable assembling processes instantly (Caudell \& Mizell, 1992). The device, developed by Thomas Caudell and David Mizell, saved time and money for the company.

Feiner, MacIntyre, Hollerer and Webster (1997) developed a touring machine for their university's campus that combines the overlaid 3D graphics of augmented reality with the untethered freedom of mobile computing. They used a head-worn 3D display and hand-held 2D display with trackpad to presents various information about the campus.

The first real mobile application of augmented reality was the ARQuake game developed by Bruce Thomas in 2000 (Thomas, Close, Donoghue, Squires, De Bondi and Piekarski, 2002). This game is the modified version of the Quake game, which was a kind of First-Person Shooter genre and first released in 1996. ARQuake game was adapted to augmented reality environment (Piekarski \& Thomas, 2002). So, The ARQuake game was the first augmented reality video game.

In 2012, Google introduced the Project Glass, which is a kind of smart glasses, an optical headmounted display designed in the shape of a pair of eyeglasses. The project glass was the perfect environment for augmented reality applications. Project Glass had lots of features like voice control, control with eye movements, video recording, photo shooting, weather control, messaging, buying tickets, etc.

Volkswagen, a German multinational automotive manufacturing company, developed MARTA (Mobile Augmented Reality Technical Assistance) in 2013 to assist workers in the production of an automobile which has lots of hardware and software components.

In 2015, Microsoft released HoloLens which was a pair of mixed reality smart glasses developed and manufactured by Microsoft. It is like Google Glass but fully supported by windows 10 computer operating system (Gümüş, 2015). HoloLens was used by NASA at 
Kennedy Space Center visitor complex in Florida for visitors to presents an interactive guided tour of an area of Mars with astronaut Buzz Aldri by creating a world in which real and virtual objects can interact (Greicius, 2016).

Nowadays augmented reality technologies are becoming widespread rapidly thanks to the developments in mobile technologies. It can be said that these technologies will be part of daily life of people in near future with affordable prices. One of the reasons for rapid widespread of augmented reality is that it can be used effectively in many fields from automobile production to simple fishing techniques. Besides the big technology giants like Google, Microsoft and Apple are very interested in augmented reality and they invest large amount of money in augmented reality.

\section{Components of Augmented Reality System}

Certain hardware and software components must be combined for an augmented reality system (Kipper \& Rampolla, 2012). In this part, hardware and software components of augmented reality systems are introduced.

\section{Hardware}

Basic hardware components, which an augmented reality system should have, are listed below (Kipper \& Rampolla, 2012):

- A computer or a mobile device

- Monitor or a kind of display screen.

- Camera

- $\quad$ Trackers and sensors (GPS, compass, accelerometer, etc.)

- $\quad$ Network infrastructure

- Pointer

Some of the hardware components listed above could be categorized differently by other researchers in literature. Furth (2011) categorized AR hardware as trackers, microprocessors, display unit, and input devices. On the other hand, Craig (2013) categorized AR hardware as microprocessors, screens and sensors (Furth, 2011 and Craig, 2013 as cited in K1lıç, 2016). In this part, components of sensors, microprocessors and displays are examined.

\section{Sensors}

Sensors are the devices that collect data about the physical world around the augmented reality system. Sensors that can used in an augmented reality system are GPS, compass, accelerometer, 
camera, object detectors, etc. These sensors send the data they collect to the augmented reality system's software to be processed.

Doubtlessly, the most important sensor of an augmented reality system is camera. Cameras collect data digitally as images or videos of a real environment and send this data to the augmented reality system's software to be processed. Image recognition is an important part of Augmented Reality systems.

Markers are the places in which real world and virtual world objects come together. An augmented reality device needs to recognize a base in real world where a virtual content can be placed. These systems are called as Marker-based AR (Kipper \& Rampolla, 2012). Most of the Marker-based AR systems uses QR (Quick Response) codes to align virtual object to real objects (K1lıç, 2016).

Markerless AR and Location based AR are the other kinds of augmented reality technologies (Rekimoto, 1998, Cheng \& Tsai, 2013). In Markerless AR systems, mostly virtual objects float around, and users are supposed to align them manually to fit the real world like a virtual furniture in a real room. Sometimes augmented reality systems detect the surrounding with AI (artificial intelligence) technology and align the virtual objects automatically. In location-based $A R$, virtual contents are tied to a specific location like a virtual road sign displaying the street name.

\section{Microprocessors}

Microprocessors process all the data collected by sensors, generate all kinds of textual and visual information and send this information to the displays to be seen by the users. Microprocessors are included in computers, tablets and smart phones. The produced output generated by microprocessors must be synchronous with the data gathered with sensors. So, the architecture of microprocessors should meet the augmented reality standards to provide a seamless augmented reality experience (Craig, 2013). Technically augmented reality systems can use central processing unit (CPU) and graphics processing unit (GPU) as a microprocessor to achieve the tasks.

\section{Displays}

Produced output of microprocessors are mostly seen on displays by users. According to Furht (2011) there are three types of displays used in augmented reality systems: Head Mounted Displays, Handheld Displays and Spatial Displays. A head-mounted display (HMD) is a display device that is worn on the head and has a small screen in front of one or two eyes (Furht, 2011). There are two kinds of HMDs: virtual reality headsets and optical head mounted displays. These two different technologies have advantages and disadvantages (Azuma, 1997). A virtual reality headset is a head-mounted device that provide small displays for each eye. With virtual reality 
headsets users don't see the surroundings directly and users enter a completely immersive virtual environment. If software supports, maybe users can see the surrounding by camera assembled in the headset. Because of the immersive virtual environment, these headsets can cause the user to experience virtual reality sickness, a kind of motion sickness. An optical headmounted display uses an optical mixer which can reflect artificial images, and let real images cross the lens. An optical head-mounted displays are more suitable for augmented reality systems by enabling user to interact with both virtual and real worlds.

Handheld Displays are the devices that generate augmented reality environment on their displays by processing the video captured by the camera instantly (Furht, 2011). Today most of the smartphones as handheld displays have the capabilities to offer augmented reality contents. Furthermore, spatial AR systems make use of digital projectors to display graphical information onto physical objects. This system enhances the real objects' appearances with materials generated virtually (Furht, 2011). For example, it is possible to see a car with different colors and patterns without really painting it with a spatial AR system. Spatial AR systems have also great potential for many sectors. Probably in near future, a lot of spatial AR systems will be released.

\section{Software}

Basic software components, which an augmented reality system should have, are listed below (Kipper \& Rampolla, 2012):

- Web services

- Content server

- An application or a program running locally.

The success of the augmented reality system depends on both hardware and software components. Software component is like a bridge between real world and virtual world.

According to Craig (2013), software can be categories in four groups as below

- $\quad$ Software involved directly in the AR application

- $\quad$ Software used to create the AR application

- $\quad$ Software used to create the content for the AR application

- $\quad$ Other software related to AR

On the other hand, according to Çakal and Eymirli (2012), software tools used in the production of augmented reality systems can be categorized as follows:

- $\quad$ Modeling tools

- Marker productions tools

- 3 D engines 
- Mobile application tools

- Web interface tools

Modelling tools are the software and hardware components that enable modeling real world objects in 3-dimensional digital environment. Unity3D, SketchUp, Blender, Cinema 4D, 3ds Max and Sweet Home 3D are the well-known examples of modeling software. WebGL, Unity3D, Papervision3D, Away3D and Sandy3D are the well-known 3D engines used in augmented reality environments (İçten \& Bal, 2017). 3D engines render virtual objects in real time and presents a realistic view of a virtual environment. 3D engine is an important software component for an augmented reality system.

Today there are software development kits (SDK) for rapid development of augmented reality systems. Some of them are open source and free, others are needed to be bought. Table 1 presents well-known SDKs as a list.

Table 1

Software development kits for augmented reality systems (Kara, 2018).

\begin{tabular}{|l|c|l|c|c|c|c|}
\hline \multicolumn{1}{|c|}{ SDK } & License & \multicolumn{1}{|c|}{ Supported Platforms } & 2D & 3D & $\begin{array}{c}\text { Geo } \\
\text { Location }\end{array}$ & $\begin{array}{c}\text { Cloud } \\
\text { Support }\end{array}$ \\
\hline Vuforia & Free & $\begin{array}{l}\text { Android, iOS, UWP and } \\
\text { Unity } \\
\text { Editor }\end{array}$ & $\checkmark$ & $\checkmark$ & $\times$ & $\checkmark$ \\
\hline EasyAR & Free & $\begin{array}{l}\text { Android, iOS, UWP, } \\
\text { Windows, Mac and Unity } \\
\text { Editor }\end{array}$ & $\checkmark$ & $\times$ & $\times$ & $\times$ \\
\hline Wikitude & Paid & $\begin{array}{l}\text { Android, iOS, Smart } \\
\text { Glasses }\end{array}$ & $\checkmark$ & $\checkmark$ & $\checkmark$ & $\checkmark$ \\
\hline ARToolKit & Free & $\begin{array}{l}\text { Android, iOS, Linux, } \\
\text { Windows, } \\
\text { MacOS and Smart Glasses }\end{array}$ & $\checkmark$ & $\times$ & $\times$ & $\times$ \\
\hline Kudan & Paid & $\begin{array}{l}\text { Android, iOS, Unity } \\
\text { Editor. }\end{array}$ & $\checkmark$ & $\checkmark$ & $\times$ & $\times$ \\
\hline Layar & Paid & Android, iOS, BlackBerry & $\checkmark$ & $\checkmark$ & $\checkmark$ & $\times$ \\
\hline NyART.Kit & Free & Android, iOS & $\checkmark$ & $\times$ & $\times$ & $\times$ \\
\hline
\end{tabular}

Today the mostly used SDK is ARToolKit which is open source and free software (İçten \& Bal, 2017). ARToolKit was first developed by Hirokazu Kato in 1999 in the Human Interface Technology Laboratory (Kato \& Billinghurst, 1999). ARToolKit also supports different languages. 


\section{Usage Areas of Augmented Reality}

Usage areas of augmented reality applications is expending every day. In this part of the paper, some of the important usage areas, like education, health, advertisement, fun, repairing and maintenance, and architecture and decoration are introduced.

\section{Education}

According to the multimedia cognitive theory, people learn better, if multiple senses are targeted simultaneously. In this context, augmented reality has a great potential for better education because it can target multiple senses of people (Luckin and Fraser, 2011). Besides it is an interesting technology, and probably students find it enjoyable. Furthermore, it can be said that augmented reality provides new opportunities, that never existed before, for education $(\mathrm{Wu}$, Lee, Chang and Liang, 2013).

Wu et al. (2013) performed a literature review study about augmented reality in education. They found that studies about augmented reality were based on the teaching or learning techniques like game-based learning, location-based learning, problem-based learning, simulation, role playing, jigsaw method. In another study, MagicBook application were created to show 3D images of the objects and cartoon characters in the book to children by markers and handheld devices. This study indicates that children liked to be a part of the story and were motivated by augmented reality application (Billinghurst, 2002)

In a comparison study, Di Serio, Ibáñez and Kloos (2013) found that attention and satisfaction level of students in a learning environments with augmented reality application were higher than the students who were in a lesson with slide based presentation. Beside they also found that augmented reality in education increased the motivation of students.

An application based on radio frequency identification (RFID) and augmented reality technologies were developed for outdoor natural science learning in a study (Liu, Tan \& Chu, 2009). Researchers used the application at the Guandu Nature Park in Taiwan to evaluate its effectiveness with elementary school students and teachers. They found that the application they used improved student learning. Similarly, in another study in England, researchers compared a learning experience based on augmented reality with traditional education. They also found that augmented reality had positive effect on students' learning (Kerawalla, Luckin, Seljeflot, and Woolard, 2006).

In literature, there were quite number of studies which indicate that proper use of augmented reality in education improves academic performance and motivation (eg. Gün, 2014, Abdüsselam, 2014). These studies showed that augmented reality gained recognition in education. It can be said that in near future augmented reality applications in education will increase gradually. According to Tech Trends published by Deloitte Insights in 2019, future 
factories will use augmented reality learning to manage the workflow in production, supply chain, etc. (Deloitte, 2019).

\section{Health}

In literature it can be said that the most of the augmented reality applications were performed in health area or medical education. In this part, summary of some studies was given as an example.

In a study, researchers developed an augmented reality navigation system using an accurate three-dimensional sensory system that can be utilized in endoscopic surgery. They used augmented reality visualization, which superimposed the visualized 3D-US images and segmented and rendered CT-based images on captured laparoscopic live images. The system provided real-time anatomical information which cannot be visualized without navigation system. And they applied their system in various clinical cases (Konishi, Hashizume, Nakamoto, Kakeji, Yoshino, Taketomi, and Maehara, 2005). It was stated that these assisting technologies are very helpful for eliminating human errors.

It was stated that in surgeries navigation system is very crucial for decreasing human errors. But navigation devices used in surgeries are very expensive, hard to use, needs preparation and leaves open the possibility for many complications. Dr. Itaru Endo and his team developed an application that helps minimize the risks involved with liver surgery. The application provides comprehensive access to three-dimensional surgical data and uses augmented reality to overlay complex vascular systems during operations (Apple, 2019).

Brown and Hua (2006) developed a Magic Lenses framework which is a augmented reality environment and makes visualization of complex objects easy to understand. And they indicated that this device can be used in medical education effectively.

\section{Advertisement}

Augmented reality is an interesting and remarkable technology that grabs attention from people. So, advertisers started to use augmented reality for their marketing purposes. For example, Smartis company developed the Doll Up augmented reality application for customers to be dressed virtually in online shopping. The application uses motion sensor, camera, and it can be controlled with simple hand movements (Smartis, 2012). In addition, the applications like Magic Mirror and Virtual Watch, which were developed with Kinect and Zugara, are being used in marketing effectively. It can be said that applications like Doll Up, Magic Mirror and Virtual Watch will be widespread in marketing in near future (İçten \& Bal, 2017). 


\section{Repairing and Maintenance}

Another mostly used areas of augmented reality are repairing and maintenance services. Augmented reality is being used in repairing, maintenance, assembly, design, etc. from automobiles to advanced space vehicles. It was stated that augmented reality saves both time and money for these processes. As well as, it eliminates human errors which can cause technical problems.

NASA develops augmented reality applications to support astronauts and engineers of the Jet Propulsion Laboratory who deals with the design and development of space vehicles (Greicius, 2016). Similarly, automobile companies also use augmented reality applications in the repair and maintenance processes intensively. For example, BMW support its service engineers with the augmented reality application which was developed for assisting repair and maintenance works (Elearningsuperstars, 2019). In addition, engineers in BMW developed Head-Up Display technology which project a screen onto the windsheild glass to assist the driver with the information of navigation, speed, traffic jams, etc. (Bimmerfile, 2011).

\section{Architecture and Decoration}

Another frequently used areas of augmented reality are architecture and decoration. A furniture company developed an augmented application, IKEA Place, for its customers to try new furniture in their own home before buying. So that, customers have the opportunity to design the interiors of their houses and compare different designs with simple clicks in the IKEA Place augmented reality software (Molla, 2017).

\section{CONCLUSION}

With the technological development especially in mobile computing, augmented reality applications started to become widespread. As a consequence, augmented reality applications can be used in many areas from education to medicine. In the future, it can be said that augmented reality technology will become a part of our daily life with many applications to make our life easier and enjoyable.

\section{Acknowledgements}

This study is based on a master's thesis completed by the first author at the Balıkesir University, Turkey, under the supervision of the second author. 


\title{
Artırılmış Gerçeklik: Tarihsel Gelişimi ve Kullanım Alanları
}

\section{Özet}

Gelișen teknoloji birçok yeniliği de beraberinde getirmektedir. Günümüzde insanlar tarafindan kullanımı yaygınlaşan bu yeniliklerden biri de artırılmış gerçeklik kavramıdır. Sanal ile gerçeğin kombinasyonunda insanlara artırılmış olarak gerçeklik deneyiminin sunulduğu ortamlar olarak ifade edilen artırılmış gerçeklik konusunda alanyazında birçok çalışma yapıldığı gözlemlenmektedir. Bu çalışmanın amacı, artırılmış gerçekliğin tarihsel gelişim ve kullanım alanları konusunda bilgi sunmaktır. Sunulan bu bilgilerin alanyazında bu konuda çalışma yapacak araştırmacılara yol gösterici bir ışık tutacağı düşünülmektedir.

Anahtar kelimeler: artırılmış gerçeklik, alanyazın taraması, karma gerçeklik, sanal gerçeklik

\begin{abstract}
About the Author(s)

\section{Serkan ÇANKAYA}

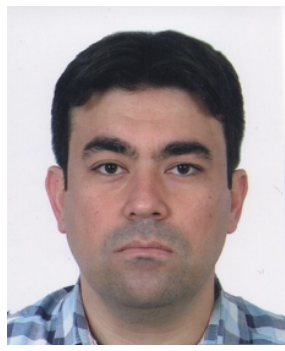

Serkan Çankaya is Associative Professor of Computer Education and Instructional Technology at İzmir Democracy University. Dr. Çankaya received his BA in Computer Education Department at Middle East Technical University and MS in Computer Education \& Instructional Technology Department at Balıkesir University. He gained his Ph.D. in Computer Education \& Instructional Technology Department at Anadolu University at June, 2013. His academic interest areas are social learning networks, educational multimedia, open and distance learning, online learning and special educational technology. He has journal articles published in international indexes, papers submitted to international meetings.

Mailing Address: İzmir Democracy University, Üçkuyular Mahallesi, Gürsel Aksel Bulvarı, No:14 35140 Karabağlar/IZMMiR

E-mail: serkan.cankaya@idu.edu.tr
\end{abstract}

\section{İbrahim SÜNGER}

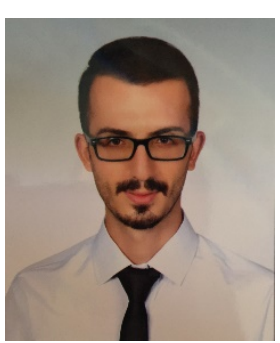

İbrahim Sünger is a information and communication technologies teacher in a private school in Ankara. Mr. Sünger received his BA in Computer Education Department at Balıkesir University and MS in Computer Education \& Instructional Technology Department at Balıkesir University in 2019. His academic interest areas are coding, robotics, virtual learning networks, educational technology and augmented reality.

Mailing Address: Özel Çankaya Doğa Koleji, Ahlatlıbel Mahallesi, 51. Cadde No:39 İncek/ANKARA E-mail: ibrahimsngr@gmail.com 


\section{References}

Abdüsselam, M. S. (2014). Artırılmış gerçeklik ortamı kullanılarak fizik dersi manyetizma konusunda öğretim materyalinin geliştirilmesi ve değerlendirilmesi. Doktora Tezi, Karadeniz Teknik Üniversitesi, Eğitim Bilimleri Enstitüsü, Ortaöğretim Fen ve Matematik Alanları Eğitimi Anabilim Dalı, Trabzon.

Altınpulluk, H. (2015). Artırılmış gerçekliği anlamak: kavramlar ve uygulamalar. Açıköğretim Uygulamalart ve Araştırmaları Dergisi, 1 (4), 123-131.

Altınpulluk, H., \& Kesim, M. (2015). Geçmişten günümüze artırılmış gerçeklik uygulamalarında gerçekleşen paradigma değişimleri. Akademik Bilişim Kongresi, 4-6.

Apple. (2019). [online]. (04.05.2019), https://www.apple.com/in/ipad/life-on-ipad/new-eyesfor-hands-on-surgery/

Azuma, R. T. (1997). A survey of augmented reality. Presence: Teleoperators \& Virtual Environments, 6 (4), 355-385.

Baum, L. F. (1901). The master key an electrical fairy tale [online]. (18.04.2019), http://www.gutenberg.org/ebooks/436?msg=welcome_stranger

Billinghurst, M. (2002). Augmented reality in education. New horizons for learning, 12 (5), 15.

Bimmerfile. (2011). BMW to Introduce Augmented Reality Heads-Up Displays [online]. (04.05.2019), http://www.bimmerfile.com/2011/10/12/bmw-to-introduce-augmentedreality-heads-up-displays/

Brown, L. D., \& Hua, H. (2006). Magic lenses for augmented virtual environments. IEEE Computer Graphics and Applications, 26 (4), 64-73.

Caudell, T. P., \& Mizell, D. W. (1992). Augmented reality: An application of heads-up display technology to manual manufacturing processes. In Proceedings of the twenty-fifth Hawaii international conference on system sciences (2, 659-669).

Cheng, K. H., \& Tsai, C. C. (2013). Affordances of augmented reality in science learning: Suggestions for future research. Journal of Science Education and Technology, 22 (4), 449-462.

Craig, A. B. (2013). Understanding Augmented Reality: Concepts and Applications. Newnes.

Çakal, M. A., \& Eymirli, E. B. (2012). “Artırılmıș Gerçeklik Teknolojisi”, Kuzeydoğu Anadolu Kalkınma Ajans1 [online]. (03.05.2019), http://www.kudaka.org.tr/ekler/fa254artirilmis_gerceklik teknolojisi.pdf

Deloitte. (2019). Tech Trends 2019 [online]. (15.05.2019), https://www2.deloitte.com/content/dam/Deloitte/br/Documents/technology/DI Tech Trends2019.pdf 
Di Serio, Á., Ibáñez, M. B., \& Kloos, C. D. (2013). Impact of an augmented reality system on students' motivation for a visual art course. Computers \& Education, 68, 586-596.

Elearningsuperstars.

(2019).

[online].

(04.05.2019),

http://www.elearningsuperstars.com/project/bmw-augmented-reality-serviceengineer-training/

Furht, B. (Ed.). (2011). Handbook of augmented reality. Springer Science \& Business Media.

Greicius, T., (2016). 'Mixed Reality' Technology Brings Mars to Earth [online]. (20.04.2019), https://www.nasa.gov/feature/jpl/mixed-reality-technology-brings-mars-to-earth

Gün, E. (2014). Artırılmış gerçeklik uygulamalarının öğrencilerin uzamsal yeteneklerine etkisi. Yüksek Lisans Tezi, Gazi Üniversitesi, Eğitim Bilimleri Enstitüsü, Bilgisayar ve Öğretim Teknolojileri Eğitimi Anabilim Dalı, Ankara.

Gümüş, F., (2015). HoloLens Nedir [online]. (20.04.2019), https://www.muhendisbeyinler.net/hololens-nedir/

İçten, T., \& Bal, G. (2017). Artırılmış Gerçeklik Teknolojisi Üzerine Yapılan Akademik Çalışmaların İçerik Analizi. Bilişsim Teknolojileri Dergisi, 10 (4), 401-415.

İçten, T., \& Bal, G. (2017). Artırılmış gerçeklik üzerine son gelişmelerin ve uygulamaların incelenmesi. Gazi Üniversitesi Fen Bilimleri Dergisi Part C: Tasarım ve Teknoloji, 5 (2), 111-136.

Isdale, J. (1993). What is virtual reality? A homebrew introduction and information resource list [online]. (20.04.2019), http://www. isdale. com/jerry/VR/WhatIsVR. html

Kapp, C., \& Balkun, M. M. (2011). Teaching on the virtuality continuum: Augmented reality in the classroom. Transformations: The Journal of Inclusive Scholarship and Pedagogy, 22 (1), 100-113.

Kara, A. (2018). Artırılmış gerçeklik uygulamalarının eğitimde kullanılmasına yönelik araştırmaların incelenmesi. Yüksek Lisans Tezi, Atatürk Üniversitesi, Ĕgitim Bilimleri Enstitüsü, Bilgisayar ve Öğretim Teknolojileri Eğitimi Anabilim Dalı, Erzurum.

Kato, H., \& Billinghurst, M. (1999). Marker tracking and hmd calibration for a video-based augmented reality conferencing system. In Proceedings 2nd IEEE and ACM International Workshop on Augmented Reality (IWAR'99) (85-94). IEEE.

Kerawalla, L., Luckin, R., Seljeflot, S., \& Woolard, A. (2006). "Making it real": exploring the potential of augmented reality for teaching primary school science. Virtual reality, 10 (3-4), 163-174.

Kılıç, T. (2016). Artırılmış gerçeklik teknolojisinin iç mekân tasarım sürecinde kullanılması. Yüksek Lisans Tezi, Mimar Sinan Güzel Sanatlar Üniversitesi, Fen Bilimleri Enstitüsü, İç Mimarlık Anabilim Dalı, İstanbul. 
Kipper, G., \& Rampolla, J. (2012). Augmented Reality: an emerging technologies guide to AR. Elsevier.

Konishi, K., Hashizume, M., Nakamoto, M., Kakeji, Y., Yoshino, I., Taketomi, A., ... \& Maehara, Y. (2005, May). Augmented reality navigation system for endoscopic surgery based on three-dimensional ultrasound and computed tomography: Application to 20 clinical cases. In International Congress Series (Vol. 1281, pp. 537542). Elsevier.

Liu, T. Y., Tan, T. H., \& Chu, Y. L. (2009). Outdoor Natural Science Learning with an RFIDSupported Immersive Ubiquitous Learning Environment. Journal of Educational Technology \& Society, 12 (4), 161-175.

Luckin, R., \& Fraser, D. S. (2011). Limitless or pointless? An evaluation of augmented reality technology in the school and home. International Journal of Technology Enhanced Learning, 3 (5), 510-524.

Ludwig, C. and Reimann, C. (2005). Augmented reality: Information at focus. C-Lab Report, $4(1), 4-15$.

Microsoft. (2019). [online]. (20.04.2019), https://www.microsoft.com/enus/hololens/hardware

Milgram, P., and Kishino, F. (1994). A taxonomy of mixed reality visual displays. IEICE TRANSACTIONS on Information and Systems, 77 (12), 1321-1329.

Molla, M. (2017). IKEA'dan Artırılmış Gerçekliği Sevdirecek Uygulama [online]. (01.05.2019), $\quad$ http://dergi.ituieee.com/teknolojik/ikeadan-artirilmis-gercekligisevdirecek-uygulama

Scopus, (2019). "augmented reality" anahtar kelimesini içeren akademik çalışmalar, Scopus Preview [Online]. (26 Mart 2019) http://www.scopus.com.

Smartis. (2012). “Türkiye'de Bir İlk: Doll Up” [online]. (05.05.2019), https://www.smartis.com.tr/blog/?p=1394

Sutherland, I. E. (1965). The ultimate display. Multimedia: From Wagner to virtual reality, 506-508.

Sung, D. (2011). The history of augmented reality [online]. (18.04.2019), http://www.pocketlint.com/news/108888-the-history-of-augmented-reality

Sutherland, I. E. (1968). A Head Mounted Three Dimensional Display, AFIPS Fall Joint Computer Conference, Washington, D.C.: Thompson Books, 1968. 757-764.

Woods, B. (2014). How augmented reality is augmenting its own future [online]. (18.04.2019), http://thenextweb.com/insider/2014/01/31/augmented-reality-augmentingfuture/\#!t4WKQ 
Wu, H. K., Lee, S. W. Y., Chang, H. Y., and Liang, J. C. (2013). Current status, opportunities and challenges of augmented reality in education. Computers \& education, 62, 41-49.

Thomas, B., Close, B., Donoghue, J., Squires, J., De Bondi, P., and Piekarski, W. (2002). First person indoor/outdoor augmented reality application: ARQuake. Personal and Ubiquitous Computing, 6 (1), 75-86.

Piekarski, W., \& Thomas, B. (2002). ARQuake: the outdoor augmented reality gaming system. Communications of the ACM, 45 (1), 36-38.

Rekimoto, J. (1998, July). Matrix: A realtime object identification and registration method for augmented reality. In Proceedings. 3rd Asia Pacific Computer Human Interaction (Cat. No. 98EX110) (63-68). IEEE. 